\title{
EFFECTS OF ANIMAL MANURES ON YIELD QUALITY AND NUTRIENT CONTENT IN ORGANIC BROCCOLI (BRASSICA OLERACEA L. VAR. ITALICA)
}

\author{
YOLDAS, F. $.^{*}-$ CEYLAN, S. ${ }^{1}-$ ElMACI, O. L. ${ }^{2}$ \\ ${ }^{1}$ Odemis Technical Training College, Ege University, Izmir, Turkey \\ ${ }^{2}$ Soil Science Department, Faculty of Agriculture, Ege University, Izmir, Turkey \\ *Corresponding author \\ e-mail: funda.yoldas@ege.edu.tr; phone: +90-542-322-53-85; fax: +90-232-544-43-56
}

(Received 29 $9^{\text {th }}$ Nov 2019; accepted 24 $4^{\text {th }}$ Mar 2020)

\begin{abstract}
This study was conducted to determine the animal manures on yield, quality, and nutrient content of broccoli heads. Treatments consisted of 0,30 and $60 \mathrm{t} \mathrm{ha}^{-1}$ of sheep and cattle manure and organic commercial fertilizer (B5A). Manure rates significantly increased yield, average weight of main and secondary heads, and the diameter in broccoli compared to control. The highest total yield $\left(27.74 \mathrm{tha}^{-1}\right)$ was obtained using sheep manure $\left(30 \mathrm{t} \mathrm{ha}^{-1}\right)$. At harvest, the highest amount of the total $\mathrm{N}$ in broccoli heads was measured at organic commercial fertilizer application. Potassium (K), sodium (Na), iron $(\mathrm{Fe})$ and manganese $(\mathrm{Mn})$ content increased with higher doses but, phosphorus $(\mathrm{P})$, calcium $(\mathrm{Ca})$, copper $(\mathrm{Cu})$ and zinc $(\mathrm{Zn})$ contents were not influenced. Additionally, the highest nutrient removal for broccoli heads was obtained at $30 \mathrm{t} \mathrm{ha}^{-1}$ sheep manure application rate.
\end{abstract}

Keywords: nutrients contents, yield, quality, removed nutrient, sheep manure, cattle manure

\section{Introduction}

Broccoli (Brassica oleracea L. var. italica) belongs to the Brassicaceae family is a perennial plant widespread in the west and northwest part of Turkey. Broccoli production in Turkey has increased considerably in recent years. The production reached 69592 tons in 2019 (Anonymous, 2019a). Broccoli is high in nutritional value and is found in the most efficient group of vegetables from the standpoint of food production. Also, Broccoli has been shown to be very useful for human health in terms of its ingredients and to provide protection against certain types of cancer (Yoldas, 2003; Yoldas and Eşiyok, 2004; Yoldas et al., 2008, 2009, 2019; Anonymous, 2019b; Vanduchova, 2019). Broccoli is not a very selective vegetable in terms of soil requirements. Soils rich in organic matter are suitable for broccoli cultivation.

Fertilization is very important for increasing yield and quality in crop production. Plant nutrition is one of the most important factors that increase plant production (Ninou et al., 2017). However, fertilizer needs vary according to varieties, soil properties, organic matter content and ecology. One of the most important problems in plant production is the accumulation of nitrate. Farmer's unconscious and excessive use of fertilizer plants may cause nitrate accumulation and environmental pollution (Mordoğan et al., 2001; Yoldas et al., 2017). Intensive fertilizer and pesticide use often leads to occurring of significant hazards for humans and their environment (Atılgan et al., 2007). The use of organic and plant-based organic substances in agriculture as an alternative to chemical fertilizer or as a way of reducing their amount is becoming widespread (Yoldas et al., 2009). Comparisons of conventional and organic farms compared to soil type indicated that organic practices improved soil quality (Liebig and Doran, 1999). 
Healthy life and environmental awareness are important today. This case it caused to increase on naturel human nutrition. Using of chemical fertilizer was decreased and natural production became important. Increasing the productivity of our soil resources by natural manure will be appropriate. Soil organic matter improves physical, chemical, biological properties of soil and is also affect the availability of nutrient (Sezen, 1995; Chaterjee et al., 2005; Kandil and Gad, 2009). In sustainable agriculture, organic fertilizers not only supply plant nutrients but also improve soil organic matter contents (Yaldiz et al., 2017). The importance of organic fertilizers in soil fertility and the fact that the soils of the region are poor organic matter in sandy texture reveals the need for organic fertilizers (Yoldas and Ceylan, 2010).

The objectives of this study were to (i) evaluate broccoli yield and yield components according to different organic manure doses, (ii) to find effects of organic manure doses on nutrient content in heads, and (iii) to determine amounts of nutrients removed by broccoli heads.

\section{Materials and methods}

This research was conducted during the winter growing season at Odemis Technical Training College of Ege University (altitude $123 \mathrm{~m}$ and $38^{\circ} 13^{\prime}$ 8.4216" North and $27^{\circ}$ 58 ' 18.3432" east). Ironmen variety was used as a test crop (the head that reaches the harvest maturity -80-85 days after transplanting- has the feature of waiting like the main head without spoiling its quality). The experiment was designed in a randomized block with three replications (in October). The experimental design included unfertilized control plots. Seeds were sown in pots which had included $105 \mathrm{ml}$ torf. They were transplanted $50 \mathrm{~cm}$ apart between plants and $70 \mathrm{~cm}$ apart in rows (Yoldas, 2003), when they became optimum size for planting. The experimental area was dripped with discharrow. Each plot area was $3.5 \mathrm{~m}^{2}$ and contained 10 plants. Marketable parts of broccoli were collected (Yoldas, 2003). Fertilizer treatments included control (no fertilizer treatment) four rates of organic manures (30, $60 \mathrm{t} \mathrm{ha}^{-1}$ sheep manure and 30, $60 \mathrm{t} \mathrm{ha}^{-1}$ cattle manure), organic commercial fertilizer (B5A-production by BMR Agriculture) were mixed with the soil before planting. In experiment, weeds are cleaned by hand during the plant development period and irrigation was conducted regularly (Vural et al., 2000).

Broccoli heads of marketable size were harvested (in February - for 1.5 months) from each plot: total yield $\left(\mathrm{t} \mathrm{ha}^{-1}\right)$, main head yield $\left(\mathrm{t} \mathrm{ha}^{-1}\right)$, secondary head of yield $\left(\mathrm{t} \mathrm{ha}^{-1}\right)$, average weight of main head $(\mathrm{g})$, average weight of secondary head $(\mathrm{g})$, diameter of head $(\mathrm{cm})$, and length of head $(\mathrm{cm})$ of broccoli were determined.

Soil samples were taken from depths of $0-30 \mathrm{~cm}$ and $30-60 \mathrm{~cm}$ of the experiment area. Samples were air dried, ground and passed through $2 \mathrm{~mm}$ sieve for the determination of chemical parameters (Kacar, 1984). Some physical and chemical characteristics of experimental soils, determined by standard analytical methods specified in Klute (1986) and Page et al. (1982).

Available $\mathrm{K}, \mathrm{Ca}$, $\mathrm{Na}$ flame photometer (Eppendorf) and $\mathrm{Mg}, \mathrm{Fe}, \mathrm{Zn}, \mathrm{Mn}$ and $\mathrm{Cu}$ were determined by atomic absorption spectrophotometer (AAS; Varian AA 240 FS) (Lindsay and Norvell, 1978; Atalay et al., 1986) some physical and chemical properties of soils before applications are given in Table 1.

When Table 1 is examined, the soil of the trial area is neutral at $30 \mathrm{~cm}$ depth. Total $\mathrm{N}$ at 0-30 cm depth low, 30-60 cm depth medium, available $\mathrm{K}$ and $\mathrm{Ca}$ content poor (Güneş 
et al., 2000), the available P content is sufficient when evaluated according to Chapman and Pratt (1982). Mg content is in good condition at both depths. Micronutrients $\mathrm{Fe}, \mathrm{Cu}$, $\mathrm{Mn}, \mathrm{Zn}$ were found to be good and adequate (Güneş et al., 2000).

Table 1. Some physical and chemical properties of soil

\begin{tabular}{c|c|c|c}
\hline Properties & Unit & $\mathbf{0 - 3 0} \mathbf{~ c m}$ & $\mathbf{3 0 - 6 0} \mathbf{~ c m}$ \\
\hline pH & & 6.60 & 7.24 \\
Total salt & $(\%)$ & 0.030 & 0.001 \\
Lime & $(\%)$ & 0.737 & 0.395 \\
Sand & $(\%)$ & 66.8 & 74.8 \\
Clay & $(\%)$ & 7.6 & 7.6 \\
Silt & $(\%)$ & 25.6 & 17.6 \\
Texture & & Sandy loam & Sandy loam \\
Organic matter & $(\%)$ & 1.17 & 1.34 \\
Total N & $(\%)$ & 0.09 & 0.04 \\
Available $\mathrm{P}$ & $\mathrm{mg} \mathrm{kg}^{-1}$ & 44 & 30 \\
Available K & $\mathrm{mg} \mathrm{kg}^{-1}$ & 79 & 44 \\
Available Ca & $\mathrm{mg} \mathrm{kg}^{-1}$ & 720 & 641 \\
Available $\mathrm{Mg}$ & $\mathrm{mg} \mathrm{kg}^{-1}$ & 181 & 172 \\
Available $\mathrm{Fe}$ & $\mathrm{mg} \mathrm{kg}^{-1}$ & 13 & 12 \\
Available $\mathrm{Cu}$ & $\mathrm{mg} \mathrm{kg}^{-1}$ & 1.0 & 0.07 \\
Available $\mathrm{Zn}$ & $\mathrm{mg} \mathrm{kg}^{-1}$ & 0.7 & 0.2 \\
Available $\mathrm{Mn}$ & $\mathrm{mg} \mathrm{kg}^{-1}$ & 14 & 6 \\
\hline
\end{tabular}

In the experiment, organic manures fermented for 6 months were used. Organic sheep and cattle manure samples were also analyzed with methods used in plant samples. The manure and broccoli heads samples were wet digested [(nitric $\left(\mathrm{HNO}_{3}\right)$ : perchloric acid $\left(\mathrm{HClO}_{4}\right)$; 4:1] for $\mathrm{P}, \mathrm{K}, \mathrm{Ca}, \mathrm{Mg}, \mathrm{Na}, \mathrm{Fe}, \mathrm{Cu}, \mathrm{Zn}$ and $\mathrm{Mn}$ analyses. Following the digestions, Quantifications were made for phosphorus colorimetric method, for $\mathrm{K}, \mathrm{Ca}$ and $\mathrm{Na}$ by flame photometer for $\mathrm{Mg}, \mathrm{Fe}, \mathrm{Cu}, \mathrm{Zn}$ and $\mathrm{Mn}$ by AAS (Moore, 1992; Campbell and Plank, 1992). Total nitrogen in plant samples was analyzed according to the modified Kjeldahl method (Baker and Thompson, 1992). The results of the analysis of organic manures are given in Table 2.

Data were analyzed using the SPSS 25.0 statistical package programme and findings were determined based on differences between the mean LSD multivariate analyses (SPSS, 2017).

\section{Yield and yield components}

Yield and some yield characteristics are presented in Table 3. Organic manure and organic commercial fertilizer (B5A) application significantly increased the total yield, yield of main and secondary heads $(\mathrm{p}<0.01)$. The highest total and secondary head yield was obtained from $30 \mathrm{t} \mathrm{ha}^{-1}$ doses of sheep manure $\left(27.74 \mathrm{t} \mathrm{ha}^{-1}\right.$ and $10.35 \mathrm{t} \mathrm{ha}^{-1}$, respectively) (Fig. 1). Also, the highest yield of main head was obtained from $30 \mathrm{t} \mathrm{ha}^{-1}$ doses of sheep manure. The yield of main head, secondary head, and total yield were increased by treatments compared with control (64\%, $45 \%$ and $13 \%$, respectively). But, 
total yield decreased with excessive sheep manure (60 $\left.\mathrm{t} \mathrm{ha}^{-1}\right)$ applications. Similar results were obtained by Zebarth et al. (1995), Babic and Elkner (2000), Belec et al. (2001).

Table 2. Results of analysis of organic manures

\begin{tabular}{c|c|c|c}
\hline Properties & Unit & Cattle manure & Sheep manure \\
\hline $\mathrm{pH}$ & & 7.75 & 8.04 \\
Total salt & $(\%)$ & 2.73 & 3.26 \\
Dry matter & $(\%)$ & 90.29 & 58.71 \\
Organic matter & $(\%)$ & 33.55 & 52.75 \\
$\mathrm{C} / \mathrm{N}$ & & 22.67 & 31.29 \\
Total N & $(\%)$ & 0.86 & 0.98 \\
$\mathrm{P}$ & $(\%)$ & 0.59 & 0.46 \\
$\mathrm{~K}$ & $(\%)$ & 1.55 & 1.03 \\
$\mathrm{Ca}$ & $(\%)$ & 2.03 & 2.20 \\
$\mathrm{Mg}$ & $(\%)$ & 0.92 & 0.40 \\
$\mathrm{Na}$ & $(\%)$ & 0.10 & 0.07 \\
$\mathrm{Fe}$ & $\mathrm{mg} \mathrm{kg}^{-1}$ & 3.19 & 1.28 \\
$\mathrm{Cu}$ & $\mathrm{mg} \mathrm{kg}^{-1}$ & 28 & 16 \\
$\mathrm{Zn}$ & $\mathrm{mg} \mathrm{kg}^{-1}$ & 536 & 202 \\
$\mathrm{Mn}$ & $\mathrm{mg} \mathrm{kg}^{-1}$ & 221 & 111 \\
\hline
\end{tabular}

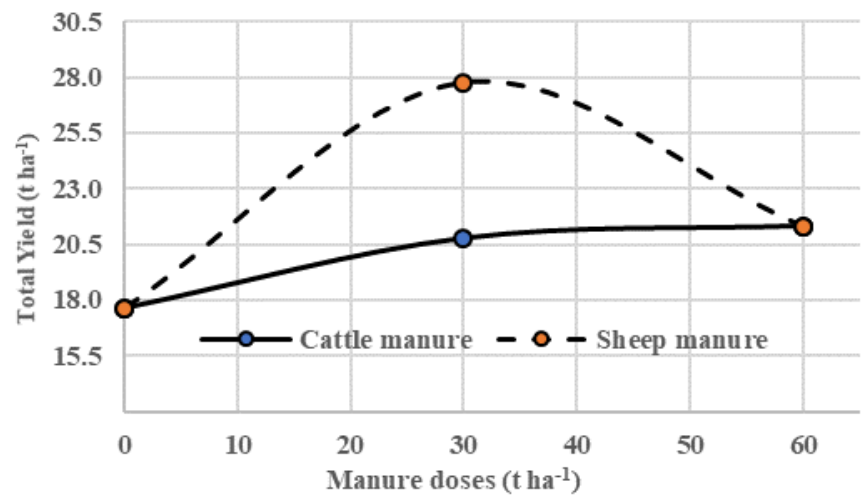

Figure 1. Effect of manure doses on total yield $\left(t h a^{-1}\right)$

But, Castellanos et al. (1999) has reported the highest marketable yield of broccoli was obtained from $400 \mathrm{~kg} \mathrm{~N} \mathrm{ha}^{-1}$. Our findings, in regards to yield, are in agreement with observations made by many researchers (Yoldas, 2003, 14.6-18.6 t ha-1; Rekowska, 2000, 18.8-19.3 t ha ${ }^{-1}$; Mihov and Antonova, 2000, 15-19.4 t ha' ${ }^{-1}$ Kunicki et al., 1999, $16.6 \mathrm{t} \mathrm{ha}^{-1}$; Albarracin et al., 1995, $20 \mathrm{t} \mathrm{ha}^{-1}$ ).

Ceylan et al. (2000) determined that the amounts of N, P, K, Ca, Mg, Fe, Cu, Zn and $\mathrm{Mn}$ in lettuce leaves increased significantly with organic fertilizer application.

Ceylan et al. (2006) found that, the maximum yield determined by using cattle manure at doses $60 \mathrm{t} \mathrm{ha}^{-1}$. When the results compared to the control, application the yield increased $21 \%$. 
Average weight of main and secondary head, weight of secondary head and diameter of head, which are the important quality criterion, were significantly increased by organic manure rates $(\mathrm{p}<0.01)$. The highest weight of head and length of head values were determined for $30 \mathrm{t} \mathrm{ha}^{-1}$ (608 g, $16.4 \mathrm{~cm}$, respectively) (Table 3). Similar results have been reported by Dellacecca et al. (1994). However, Griffith and Carling (1991), Kunicki et al. (1999), Callens et al. (2000) and Yoldas et al. (2008) found smaller head diameters than ours. Head diameter was found 16.2-16.3 cm by Albarracin et al. (1995).

Secondary head's weight was changed by an increase of manure doses (Table 3). Increasing manure rates significantly increased head diameter compared to the control. The highest value was recorded from sheep manure $\left(30 \mathrm{t} \mathrm{ha}^{-1}\right)$. It again decreased with increasing doses. There was not significant effect of treatments on length of head.

Table 3. The effects of treatments on yield and yield components (total yield (TY, $t$ ha $\left.{ }^{-1}\right)$, main head yield (Mhy, $t \mathrm{ha}^{-1}$ ), secondary head of yield (Shy, $t$ ha $\left.{ }^{-1}\right)$, average weight of main head (Awh, g), average weight of secondary head (Awsh, $g$ ), diameter of head (Dh, cm), length of head (Lh, $\mathrm{cm})$ of broccoli

\begin{tabular}{c|c|c|c|c|c|c|c}
\hline & TY & Mhy & Shy & Awh & Awsh & Dh & Lh \\
\hline Rates & $\mathrm{t} \mathrm{ha}^{-1}$ & $\mathrm{tha}^{-1}$ & $\mathrm{tha}^{-1}$ & $(\mathrm{~g})$ & $(\mathrm{g})$ & $(\mathrm{cm})$ & $(\mathrm{cm})$ \\
Control & $17.63 \mathrm{c}$ & $13.05 \mathrm{c}$ & $4.58 \mathrm{~b}$ & $457 \mathrm{c}$ & $160 \mathrm{~b}$ & 14.5 & 13.7 \\
Organic commercial fertilizer (B5A) & $19.06 \mathrm{bc}$ & $13.91 \mathrm{bc}$ & $5.14 \mathrm{~b}$ & $487 \mathrm{bc}$ & $180 \mathrm{~b}$ & 13.9 & 14.6 \\
Cattle manure 30 $\mathrm{t} \mathrm{ha}^{-1}$ & $20.76 \mathrm{~b}$ & $14.46 \mathrm{bc}$ & $6.30 \mathrm{~b}$ & $506 \mathrm{bc}$ & $221 \mathrm{~b}$ & 14.8 & 14.2 \\
Cattle manure 60 $\mathrm{t} \mathrm{ha}^{-1}$ & $21.31 \mathrm{~b}$ & $15.73 \mathrm{ab}$ & $5.58 \mathrm{~b}$ & $550 \mathrm{ab}$ & $195 \mathrm{~b}$ & 14.0 & 13.8 \\
Sheep manure 30 t ha & $27.74 \mathrm{a}$ & $17.39 \mathrm{a}$ & $10.35 \mathrm{a}$ & $608 \mathrm{a}$ & $362 \mathrm{a}$ & 15.2 & 16.4 \\
Sheep manure 60 $\mathrm{t} \mathrm{ha}^{-1}$ & $21.29 \mathrm{~b}$ & $14.35 \mathrm{bc}$ & $6.94 \mathrm{~b}$ & $502 \mathrm{bc}$ & $243 \mathrm{~b}$ & 15.6 & 15.3 \\
Minimum & 17.63 & 13.05 & 4.58 & 457 & 160 & 13.9 & 13.7 \\
Maximum & 27.74 & 17.39 & 10.35 & 608 & 243 & 15.6 & 16.4 \\
LSD & $2.904 * *$ & $2.473 * *$ & $3.107 * *$ & $86.979 * *$ & $108.99 * *$ & $n s$ & $n s$ \\
\hline
\end{tabular}

a, b, c, d: average which is shown with different letters in the same column, is between differences are significant

${ }^{* *}$ The difference is significant at the $\mathrm{P}<0.01$ level. ns: No significant difference

\section{Mineral contents of broccoli head}

Mineral contents of broccoli head are given in Table 4. K, Na, Fe and Mn contents in broccoli head were significantly affected by sheep and cattle manure treatments $(\mathrm{p}<0.01)$. Highest $\mathrm{K}$ and $\mathrm{Fe}$ content in broccoli were determined in the parcels which the cheap manure was applied as $60 \mathrm{t} \mathrm{ha}^{-1}$. The effect of organic manure on Fe-uptake at these doses, could be due to the reason that organic carbon acts as a source of energy for soil microorganism, which upon mineralization releases organic acids that decreased soil $\mathrm{pH}$ and improves availability of makes Fe (Bokhtiar and Sakurai, 2005). However highest $\mathrm{Na}$ content in the heads were obtained in the parcels which the animal manure was applied compared to the control and organic commercial fertilizer parcels.

Nitrogen is the most recognized in plants for its presence in the structure of the protein molecule (Ninou et al., 2017). In this study, it was determined that maximum $\mathrm{N}$ content in the heads were obtained by organic commercial fertilizer applied. However, significant effect of the applications has not been determined statistically on the nitrogen content of broccoli. This result may be due to low nitrogen content of soils before planting and slow release of organic fertilizers and their effects on the 
subsequent products. $\mathrm{P}, \mathrm{K}, \mathrm{Ca}$ and $\mathrm{Zn}$ contents were reached maximum at $60 \mathrm{t} \mathrm{ha}^{-1}$ sheep manure. But, N, P, Ca, Mg, Cu and $\mathrm{Zn}$ in head were not significantly affected by applications.

Table 4. The effects of treatments on macro and micro element contents in head of broccoli

\begin{tabular}{c|c|c|c|c|c|c|c|c|c|c}
\hline & \multicolumn{9}{|c}{$\%$} & \multicolumn{6}{c}{$\mathbf{m g ~ k g}^{-1}$} \\
\hline Rates & $\mathrm{N}$ & $\mathrm{P}$ & $\mathrm{K}$ & $\mathrm{Ca}$ & $\mathrm{Mg}$ & $\mathrm{Na}$ & $\mathrm{Fe}$ & $\mathrm{Cu}$ & $\mathrm{Mn}$ & $\mathrm{Zn}$ \\
Control & 5.80 & 0.22 & $3.36 \mathrm{~b}$ & 1.12 & 0.36 & $583 \mathrm{~b}$ & $74.33 \mathrm{ab}$ & 4.90 & $23 \mathrm{~b}$ & 77.00 \\
Organic commercial fertilizer (B5A) & 6.33 & 0.21 & $3.44 \mathrm{~b}$ & 1.06 & 0.40 & $598 \mathrm{~b}$ & $63.67 \mathrm{~b}$ & 5.00 & $31 \mathrm{a}$ & 75.00 \\
Cattle manure 30 $\mathrm{t} \mathrm{ha}^{-1}$ & 5.70 & 0.21 & $3.25 \mathrm{~b}$ & 1.03 & 0.36 & $771 \mathrm{a}$ & $63.33 \mathrm{~b}$ & 5.03 & $22.33 \mathrm{~b}$ & 73.66 \\
Cattle manure 60 $\mathrm{t} \mathrm{ha}^{-1}$ & 6.17 & 0.22 & $3.71 \mathrm{ab}$ & 1.13 & 0.31 & $788 \mathrm{a}$ & $74.67 \mathrm{ab}$ & 5.90 & $25.67 \mathrm{~b}$ & 74.67 \\
Sheep manure 30 $\mathrm{t} \mathrm{ha}^{-1}$ & 5.90 & 0.21 & $3.88 \mathrm{ab}$ & 1.12 & 0.34 & $665 \mathrm{ab}$ & $90.33 \mathrm{a}$ & 4.87 & $23 \mathrm{~b}$ & 74.67 \\
Sheep manure 60 $\mathrm{t} \mathrm{ha}^{-1}$ & 6.03 & 0.22 & $4.31 \mathrm{a}$ & 1.13 & 0.33 & $759 \mathrm{a}$ & $57.67 \mathrm{~b}$ & 5.30 & $22.33 \mathrm{~b}$ & 79.67 \\
Minimum & 5.70 & 0.21 & 3.25 & 1.03 & 0.31 & 583 & 57.67 & 4.87 & 22.33 & 73.66 \\
Maximum & 6.33 & 0.22 & 4.31 & 1.13 & 0.40 & 788 & 90.33 & 5.90 & 25.67 & 79.67 \\
LSD & $\mathrm{ns}$ & $\mathrm{ns}$ & $0.691^{* *}$ & $\mathrm{~ns}$ & $\mathrm{~ns}$ & $157.15^{* *}$ & $17.769^{* *}$ & $\mathrm{~ns}$ & $5.036^{* *}$ & $\mathrm{~ns}$ \\
\hline
\end{tabular}

$\mathrm{a}, \mathrm{b}, \mathrm{c}, \mathrm{d}$ : average which is shown with different letters in the same column, is between differences are significant

The difference is significant at the $\mathrm{P}<0.01$ level. ns: No significant difference

\section{Removed minerals by yield (broccoli head)}

Amount of removed minerals by broccoli head were increased by treatments compared with control generally (Table 5). These increases were statistically significant for $\mathrm{P}, \mathrm{K}, \mathrm{Mg}, \mathrm{Fe}$ and $\mathrm{Mn}(\mathrm{p}<0.05)$.

Table 5. The effects of treatments on removed nutrients amount by heads

\begin{tabular}{|c|c|c|c|c|c|c|c|c|c|c|}
\hline & \multicolumn{5}{|c|}{$\%$} & \multicolumn{5}{|c|}{$\mathrm{mg} \mathrm{kg}^{-1}$} \\
\hline Rates & $\mathrm{N}$ & $\mathrm{P}$ & $\mathrm{K}$ & $\mathrm{Ca}$ & $\mathrm{Mg}$ & $\mathrm{Na}$ & $\mathrm{Fe}$ & $\mathrm{Cu}$ & $\mathrm{Mn}$ & $\mathrm{Zn}$ \\
\hline Control & 0.09 & $15.3 \mathrm{~b}$ & $220.6 \mathrm{c}$ & 896 & $93.00 \mathrm{c}$ & 34.33 & $6.83 \mathrm{ab}$ & 1.08 & $4.17 \mathrm{a}$ & 1.59 \\
\hline Organic commercial fertilizer (B5A) & 0.10 & $16.3 \mathrm{~b}$ & $230.3 \mathrm{c}$ & 1024 & $109.66 \mathrm{~b}$ & 35.00 & $6.07 \mathrm{~b}$ & 1.09 & $4.33 \mathrm{a}$ & 1.51 \\
\hline Cattle manure $30 \mathrm{t} \mathrm{ha}^{-1}$ & 0.10 & $25.3 \mathrm{ab}$ & $287.6 \mathrm{bc}$ & 1152 & $182.66 \mathrm{ab}$ & 45.33 & $8.38 \mathrm{a}$ & 1.17 & $4.33 \mathrm{a}$ & 1.76 \\
\hline Cattle manure $60 \mathrm{t} \mathrm{ha}^{-1}$ & 0.11 & $26.7 \mathrm{a}$ & $397.3 \mathrm{a}$ & 1166 & $231.66 \mathrm{a}$ & 39.66 & $5.61 \mathrm{~b}$ & 0.81 & $2.51 \mathrm{~b}$ & 1.62 \\
\hline Sheep manure $30 \mathrm{t} \mathrm{ha}^{-1}$ & 0.11 & $18.3 \mathrm{ab}$ & $317.0 \mathrm{~b}$ & 1056 & $167.00 \mathrm{abc}$ & 35.00 & $6.15 \mathrm{~b}$ & 0.92 & $2.75 \mathrm{~b}$ & 1.64 \\
\hline Sheep manure $60 \mathrm{t} \mathrm{ha}^{-1}$ & 0.11 & $27.3 \mathrm{a}$ & 334.ab & 1152 & $181.66 \mathrm{ab}$ & 36.00 & $7.39 \mathrm{ab}$ & 1.18 & $4.49 \mathrm{a}$ & 1.95 \\
\hline Minimum & 0.09 & 15.3 & 220.6 & 896 & 93.00 & 34.33 & 5.61 & 0.81 & 2.51 & 1.51 \\
\hline Maximum & 0.11 & 27.3 & 397.3 & 1166 & 231.66 & 45.33 & 8.38 & 1.18 & 4.49 & 1.95 \\
\hline LSD & ns & $7.882 *$ & $77.092 * *$ & ns & $86.908 * *$ & ns & $1.986^{*}$ & ns & $1.381 * *$ & ns \\
\hline
\end{tabular}

$\mathrm{a}, \mathrm{b}, \mathrm{c}, \mathrm{d}$ : average which is shown with different letters in the same column, is between differences are significant

*The difference is significant at the $\mathrm{P}<0.05$ level. ns: No significant difference

The highest amount of $\mathrm{P}, \mathrm{K}, \mathrm{Mg}, \mathrm{Fe}$ and $\mathrm{Mn}$ removed was achieved at the rate of $60 \mathrm{t} \mathrm{ha}^{-1}$ sheep manure, $60 \mathrm{t} \mathrm{ha}^{-1}$ cattle manure, $60 \mathrm{t} \mathrm{ha}^{-1}$ cattle manure, $30 \mathrm{t} \mathrm{ha}^{-1}$ cattle manure and $60 \mathrm{t} \mathrm{ha}^{-1}$ sheep manure doses, respectively.

Rincon et al. (1999) have shown that removed total quantity of $\mathrm{N}, \mathrm{P}, \mathrm{K}, \mathrm{Ca}$ and $\mathrm{Mg}$ by crop were $243.9,28.7,240.9,221.3$, and $23.0 \mathrm{~kg} \mathrm{ha}^{-1}$, respectively.

It was determined that the amount of removed minerals by broccoli head were highest at the $60 \mathrm{t} \mathrm{ha}^{-1}$ sheep manure and $60 \mathrm{t} \mathrm{ha}^{-1}$ cattle manure doses, at which maximum total yield was also obtained. 


\section{Conclusions}

Increasing health problems is also noteworthy the use of friendly organic fertilizers. Slow release organic fertilizers are beneficial for production with these properties. However, environmental pollution can be prevented by conscious use.

According to the results, increasing the application dose of organic manure increased the yield. The highest yield was obtained from supplying $30 \mathrm{t} \mathrm{ha}^{-1}$ sheep manure. Therefore, $30 \mathrm{t} \mathrm{ha}^{-1}$ sheep manure application can be recommended for broccoli under these conditions. In broccoli head, $\mathrm{K}, \mathrm{Na}, \mathrm{Fe}$, and $\mathrm{Mn}$ contents, which are the important for healthy nutrition, increased with increases in organic manure doses.

Acknowledgements. This research is a work supported by Scientific Research Project Commission of Ege University; Contact no: 2010/OMYO/002.

\section{REFERENCES}

[1] Albarracin, M., Berbin, C., Machado, W. (1995): Agronomic evaluation of broccoli (Brassica oleracea var. Italica) cultivars. - Revista de la Facultad de Agronomia, Universidad Central de Venezuela, Caracas, Venezuela 21(1-2): 71-83.

[2] Anonymous (2019a): Agricultural Statistics. TUIK 2018 Data. (Tarım İstatistikleri. TUIK 2018 y1lı verileri). - Turkish Statistical Institute, Ankara.

[3] Anonymous (2019b): The amazing health benefits of broccoli. http://organicjar.com/2009/2001/The Amazing Health Benefits of Broccoli, 2019.

[4] Atalay, İ. Z., Kılıç, R., Anaç, D., Yokaş, İ. (1986): Potassium status of rendzina soils in Gediz Basin and methods to be used in determining the amount of potassium that can be taken in these soils. (Gediz havzası rendzina topraklarının potasyum durumu ve bu topraklarda alınabilir potasyum miktarının tayininde kullanılacak yöntemler.) - Bilge Printing, Izmir.

[5] At1lgan, A., Coskan, A., Saltuk, B., Erkani, M. (2007): The level of chemical and organic fertilizer usage and potential environmental impacts in greenhouses in Antalya region. Ekoloji 15: 37-47.

[6] Babic, I., Elkner, K. (2000): The effect of nitrogen fertilization and irrigation on yield and quality of broccoli. - Acta Horticulturae 571: 33-43

[7] Baker, W. H., Thompson, T. L. (1992): Determination of Total Nitrogen in Plant Samples by Kjeldahl. - In: Plank, C. O. (ed.) Plant Analysis Reference Procedures for the Southern Region of the United States, Southern Cooperative Series Bulletin 368. North Carolina Agricultural Research Service, Raleigh, NC, pp. 13-16.

[8] Belec, C., Villeneuve, S., Coulombe, J., Tremblay, N. (2001): Influence of nitrogen fertilization on yield, hollow stem incidence and sap nitrate concentration in broccoli. Can. J. Plant Sci. 81: 765-772.

[9] Bokhtiar, S. M., Sakurai, K. (2005): Integrated use of organic manure and chemical fertilizer on growth, yield and quality of sugarcanes in high Ganges River floodplain soils of Bangladesh. - Soil Sci. Plant Analysis 36: 1823-37.

[10] Callens, D., Reycke, L' de., Reycke, D., Rooster, L. (2000): Cultivar trial for early cultivation of broccoli planting date determines cultivar choice. - Proeftuinnieuws 10(1): 40-41.

[11] Campbell, R. C., Plank, C. O. (1992): Sample Preparation. - In: In: Plank, C. O. (ed.) Plant Analysis Reference Procedures for the Southern Region of the United States, Southern Cooperative Series Bulletin 368. North Carolina Agricultural Research Service, Raleigh, NC, pp. 5-7. 
[12] Castellanos, J. Z., Lazcano, I., Sosa-Balbidia, A., Badillo, V., Villalobos, S. (1999): Nitrogen fertilization and plant nutrient status monitoring-the basis for high yields and quality of broccoli in potassium-rich vertisols of central Mexico. - Better Crops International 13(2): 25-27.

[13] Ceylan, Ş., Yoldas, F. (2010): Compost, Green fertilizer and animal fertilizers in organic agriculture. (Organik Tarımda Kompost, Yeşil Gübre ve Hayvansal Gübrelerin Kullanımı.) - IV. Organic Agriculture Symp., 28 June - 1 July, 2010, Erzurum, Turkey, pp. 646-649.

[14] Ceylan, Ş., Yoldas, F., Mordoğan, N., Çakıc1, H. (2000): Effect of different cattle fertilizers on yield and quality in tomato cultivation. (Domates Yetiştiriciliğinde Farklı Sığır Gübrelerin Verim ve Kaliteye Etkisi.) - III. Symposium on Vegetable Agriculture, September 11-13, 2000, Isparta, pp. 51-55.

[15] Ceylan, S., Mordogan, N., Akdemir, H., Cakici, H. (2006): Effect of organic fertilizers on some agronomic and chemical properties of potato (Solanum tuberosum L.). - Asian J. Chem. 18(2): 1223-1230.

[16] Chapman, H. D., Pratt, P. F. (1982): Methods of Analysis for Soils Plants and Waters. University of California, Division of Agricultural Sciences, USA.

[17] Chaterjee, B., Ghanti, P., Thapa, U., Tripathy, P. (2005): Effect of organic nutrition in sprout broccoli (Brassica oleraceae var.). - Vegetable Science 33(1): 51-54.

[18] Dellacecca, V., Dias, J. S., Crute, I., Monteiro, A. A. (1994): New agro techniques to promote broccoli picking. - International Symposium on Brassicas. Ninth Crucifer Genetics Workshop, 15-18 Nov. 1994, Lisbon, Portugal. Acta Horticulturae 407: 347351.

[19] Elkner, F., Peschke, H., Köhn, W., Chmielewski, F., Baumecker, M. (2000): Tillage and fertilizing effects on sandy soils. - J. Plant Nut. Soil. Sci. 163: 267-272.

[20] Griffith, M., Carling, D. D. (1991): Effects of plant spacing on broccoli yield and hollow stem in Alaska. - Can. J. Plant Sci. 71: 579-585.

[21] Güneş, A., Alpaslan, M., İnal, A. (2000): Plant Nutrition and Fertilization. (Bitki Besleme ve Gübreleme.) - Ankara University, Faculty of Agriculture, Publication No: 1514, Ankara.

[22] Kacar, B. (1984): Plant Nutrition Application Guide. (Bitki besleme uygulama kilavuzu.) - Ankara University Faculty of Agriculture, Ankara.

[23] Kandil, H., Gad, N. (2009): Effects of inorganic and organic fertilizers on growth and production of broccoli (Brassica oleracea L.). - Factori şi Procese Pedogenetice din Zona Temperată 8(S. nouă): 61-69.

[24] Klute, A. (ed.) (1986): Methods of Soil Analysis. Part 1. Physical and Mineralogical Methods. 2nd Ed. Agron. Monogr. 9. - ASA and SSSA, Madison, WI.

[25] Kunicki, E., Capecka, E., Siwek, P., Kalisz, A. (1999): The effect of plant spacing on the yield and quality for three broccoli cultivars in autumn growing. - Folia Horticulturae 11: 69-79.

[26] Liebig, M. A., Doran, J. W. (1999): Impact of organic production practices on soil quality indicators. - J. Environ. Qual. 28: 1601-1609.

[27] Lindsay, W. L., Norvell, W. A. (1978): Development of a DTPA soil test for zinc, iron, manganese and copper. - Soil Science Society of American J. (42): 421-428.

[28] Mihov, K., Antonova, G. (2000): Assessment of broccoli (Brassica oleracea var. Italica Pl.) hybrids for late field production. - Cruciferae Newsletter 22: 85-86.

[29] Moore, K. P. (1992): Determination of phosphorus in plant tissue by colorimetry. - In: Plank, C. O. (ed.) Plant Analysis Reference Procedures for the Southern Region of the United States, Southern Cooperative Series Bulletin 368. North Carolina Agricultural Research Service, Raleigh, NC, pp. 29-31.

[30] Mordoğan, N., Ceylan, Ş., Çakıc1, H., Yoldas, F. (2001): The effect of nitrogen fertilization on nitrogen accumulation in lettuce. (Azotlu Gübrelemenin Marul Bitkisindeki Azot Birikimine Etkisi.) - Ege Univ. Zir Fak. Bull. 38(1): 85-92. 
[31] Ninou, E. G., Paschalidis, K. A., Mylonas, I. G., Vasilikiotis, C., Mavromatis, A. G. (2017): The effect of genetic variation and nitrogen fertilization on productive characters of Greek oregano. - Acta Agriculture Scandinavia, Section B-Soil \& Plant Science 67(4): 372-9.

[32] Page, A. L., Miller, R. H., Keeney, D. R. (eds.) (1982): Methods of Soil Analysis. Part 2. Chemical and Microbiological Properties. ${ }^{\text {nd }}$ Ed. Agron. Monogr. 9. - ASA and SSSA, Madison, WI.

[33] Rekowska, E. (2000): Effect of cultivars and sowing date on the yielding of broccoli. Biologiczne i Agrotechniczne Czynniki Plonowania i Jakosci Warzyw, Lublin, Polska, 15-16 Czerwca 2000. Annals Universitatis Mariae Curie Sklodowska, Sectio EEE, Horticultura 8(Suppl.): 61-66.

[34] Rincon, L., Saez, J., Perez-Crespo, J. A., Gomez Lopez, M. D., Pellicer, C. (1999): Growth and nutrient absorption of broccoli. - Investigacion Egraria Proccion y Proccion Vegetables 14(1-2): 225-236.

[35] Sezen, Y. (1995): Soil Chemistry Edition of Ataturk University No: 790. - Erzurum Atatürk Univ. Faculty of Agriculture. No: 322. Series of Lesson Book, 71.

[36] SPSS (2017): IBM SPSS Statistics Base 25. - IBM, New York.

[37] Vanduchova, A., Anzenbacher, P., Anzenbacherova, E. (2019): Isothiocyanate from broccoli, sulforaphane, and its properties. - Journal of Medicinal Food 22(2). https://doi.org/ 10.1089/ jmf.2018. 0024.

[38] Vural, H., Esiyok, D., Duman, I. (2000): Vegetable Production. - Aegean University Press, Bornova, Izmir.

[39] Yaldız, A., Arıc1, Y. K., Yılmaz, G. (2017): Phytochemical analysis, antioxidant and antibacterial activities of four Lamiaceae species cultivated in barnyard manure. - Journal of Agricultural Sciences. 2017(23): 95-108.

[40] Yoldas, F. (2003): Effects of temperature different plant spacing sowing and planted dates on plant growth and yield of broccoli cultivars. - PhD Thesis, Ege University, Graduate School of Natural and Applied Sciences, Izmir.

[41] Yoldas, F., Ceylan, Ş. (2010): Determinants of organic agriculture in Turkey; production areas and product designs. (Türkiye'de Organik Tarımı Belirleyen Faktörler, Üretim Alanları ve Ürün Desenleri.) - Turkey IV. Organic Agriculture Symposium, June 28 July 1, 2010, Erzurum, Turkey, pp. 732-735.

[42] Yoldas, F., Eşiyok, D. (2004): Effects of planting frequency, sowing and planting times on yield and quality parameters in broccoli. (Dikim Sıklı̆̆ 1 , Ekim ve Dikim Zamanlarının Brokolide Verim ve Kalite Parametreleri Üzerine Etkileri.) - Ege Univ. Faculty of Agriculture Bull. 41(2): 37-48.

[43] Yoldas, F., Ceylan, S., Yagmur, B., Mordogan, N. (2008): Effects of nitrogen fertilizer on yield quality and nutrient content in broccoli. - Journal of Plant Nutrition 31(7): 13331343. DOI: $10.1080 / 01904160802135118$.

[44] Yoldas, F., Ceylan, Ş., Elmaci, Ö. L. (2009): The influence of organic and inorganic fertilizer on yield, quality and nutrient content in processing tomato. - Ege Üniv. Zir. Fak. Derg. 46(3): 191-197.

[45] Yoldas, F., Ceylan, S., Mordogan, N., Ongun, A. R. (2017): Effects of organic chicken manure on nitrate accumulation and nutrient element content of broccoli. - Acta Biologica Turcica 30(4): 169-173.

[46] Yoldas, F., Ceylan, S., Mordogan, N. (2019): Residue effect of chicken manure on yield and yield criteria of onion (Allium cepa L.) as second crop. - Applied Ecology and Environmental Research 17(5): 12639-12647.

[47] Zebarth, B. J., Bowen, P. A., Toivonen, P. M. A. (1995): Influence of nitrogen fertilization on broccoli yield, nitrogen accumulation and apparent fertilizer-nitrogen recovery. - Can. J. Plant Sci. 75: 717-725. 